\title{
Socio-Economic Determinants of Sweet Melon Production in Balanga Local Government Area of Gombe State, Nigeria
}

\author{
Omorogbe I*, Aina OS, Yakubu SA and Hassan AA \\ Department of Agricultural Extension and Management, Federal College of Horticulture, Dadin-kowa, Gombe State, Nigeria,
}

\begin{abstract}
The potentials of the horticulture sub-sector in solving the prevailing food crisis in Nigeria remain largely untapped because of inefficient use of production resources. The study examined socio-economic determinant of sweet melon production in Balanga local government area of Gombe state. A two stage sampling procedure was used in drawing a sample size of sixty sweet melon farmers from three communities. Data collected were analyzed using both descriptive and multiple regression models. The result revealed that the majority of the farmers were male, married, and literate, with small holding. A coefficient of multiple determinants, $R^{2}$ of 0.765 indicated a high relevance of the input in explaining the observed variation in melon production. The regression co-efficient of experiences, farm size and house hold size were significant at $5 \%$ level of probability, therefore, making the three factors important determinant of output from sweet melon production. Based on findings from the study, it is recommended that government should provide credit facilities with less bureaucracy and low interest rate to producers; this will enable farmers to increase their farm size and in turn increase output.
\end{abstract}

Keywords: Socio-economic; Determinant; Sweet melon; Production; Balanga

\section{Introduction}

Sweet Melon (Cucumis melon L.) is a warm, long season horticultural crop that is adapted to all climatic zones. Annual world production of melon has increased from 9 million $(700,000 \mathrm{ha})$ in 1992 to 22 million (1.2 million ha) in 2002. Major producing countries are China with 400,000 ha, West Asia (Turkey, Iran, Iraq) 200,000 ha, the America (United State, Mexico, Central and South American countries) 165,000 ha, Northern African (Egypt, Morocco, Tunisia 110,000 ha. Southern Asia (India, Pakistan, Bangladesh 100, 000 ha). European Union (Spain, Italy, France Greece, Portugal) 95,000 ha, Romania 50,000 ha Japan 13,000 ha and Korean republic 11,000 ha FAO [1]. Each country has its own specific melon cultivars of the crop which are sold in local markets. In Africa, it is an economic crop for urban markets, grown in drier region and non-high lands. Statistics on production and marketing in Africa are not available for most countries except Cameroon (3500 ha) and Sudan (1200 ha), Senegal and surrounding countries are exporting the melon during the winter to Europe FAO [1]. Mature fruits of sweet melon cultivars are usually consumed fresh for the sweet and juicy pulp. The pulp is also mixed with water and sugar or sometimes with milk, and served as a refreshing drink or made into ice cream. Immature fruits of non-sweet types, including snake melon are used as a fresh cooked or pickled vegetable. They can also be stuffed with meat, rice and spice, and fried in oil. Sweet melon is often confused with cucumber and often used as such. The seeds are eaten after roasting they contain edible oil. The Hausa people in Nigeria grind the kernels to a paste and make it into fermented cakes. The young leaves are occasionally consumed as a pot herb and in soups. The leafy stem and also the fruit provide good forage for all livestock. In reunion and Mauritius a decoction of seeds and roots is used as a diuretic and vermifuge [2].

Sugar content and aroma are important factors determining the quality of sweet melon. Esters derived from amino acids are important components of the characteristics flavour, sulphur containing compound also play a role. Several C-9 alcohol and aldehydes, including Z-non 6-Enal, are characteristics of the melon aroma. To get the best aroma fruits should be harvested only 2-3 days before they are fully ripe. The edible seed kernel contains approximately $46 \%$ of yellow oil and $36 \%$ protein [3].

Given the increasing popularity and importance of sweet melon as a desert to many households in Nigeria, it is imperative to understand the problems facing the producers of sweet melon. Olukosi and Isitor [4] identified several possible factors that are constraints to production of fruit and vegetables. These include low farm gate price, high cost of labor input, inadequate supply of improve inputs and inefficient marketing system Due to the increasing demand and importance of sweet melon, venturing in to its enterprise holds promising potentials. However, there is little or no attention given to sweet melon production technology while only a few is done on its marketing as well. Thus, there is need for further investigation into socio-economic determinants of sweet melon production in Balanga local government area of Gombe state and also determine the factors influence sweet melon production in the study area.

\section{Problems of sweet melon production}

According to Adamu et al. [5], in his studies of profitability of sweet melon production and marketing in Kirfi Local Government Area; Bauchi State shows that majority $(87.5 \%)$ of the producers and marketers face the problem of transportation due to poor feeder roads, similarly (50\%) and (62.5\%) of the producers and marketers experienced inadequate capital to improve their productivity and farming business

*Corresponding author: Isaac Omorogbe, Department of Agricultural Extension and Management, Federal College of Horticulture, Dadin-kowa, PMB 108, Gombe State, Nigeria, Tel: 08035780411; E-mail: omoisaac2000@yahoo.co.uk, ainaosunday@hotmail.com

Received December 05, 2016; Accepted January 23, 2017; Published January 30, 2017

Citation: Omorogbe I, Aina OS, Yakubu SA, Hassan AA (2017) Socio-Economic Determinants of Sweet Melon Production in Balanga Local Government Area of Gombe State, Nigeria. J Biodivers Endanger Species 5: 180. doi: 10.4172/23322543.1000180

Copyright: (c) 2017 Omorogbe I, et al. This is an open-access article distributed under the terms of the Creative Commons Attribution License, which permits unrestricted use, distribution, and reproduction in any medium, provided the original author and source are credited. 
respectively. Moreover, $75 \%$ and $37.5 \%$ of the producers and marketers complained of glut (on-season problem) respectively.

It is noteworthy that about $31.3 \%, 56.3 \%$ and $81.3 \%$ of all the producers complained of inadequate improved seeds, labor, disease attack as well as low farm gate price respectively. This indicated that water melon producers in the study area undergo the water melon business under unpredictable situation as was also reported by Singh [6], for vegetable and tomato producers in the semi-arid regions and Yamaltu Deba Local Government Areas of Gombe State, Nigeria. Similarly, other authors reported many problems that are limiting the fruit production as, Dieter [7], shows that in his report, fluctuation in the price of fruit also contributes a major problem in its business. Agricultural production has been increasing at (2\%) two percent per year while demand has been increasing at slightly less rapid rates. This means that agricultural prices income have to be low. Similarly Adegeye and Dittoh [8], reported that prices of fruits and other agricultural produce are often manipulated by speculators with adverse effects on the producers and the consumers there is too much seasonal variation in price due mainly to lack of storage facilities and insufficient supply. Also according to the Abbott [9], shows that most fruit do not have adequate storage or ware housing facilities. The existing infrastructural facilities such as access roads, transport, market storage and processing are far from being adequate Singh [6]. Food processing plants are virtually none existing. These pose a serious problem for effectively processing of agricultural producers.

Hence, affect the effective production of fruit and other agricultural produce. In the same studies carried by Adegeye and Dittoh [8], also reported that some marketing problems can be traced to lack of information about production, for example sellers may not be able to identify source of supply of commodities, while producers may curtail their production as a result of poor sales. Therefore, there must be an information system where buyer and seller can be aware of each other problems. Also according to them, the problem of transport in marketing of fruit and vegetables has many dimension, in some cases there are insufficient vehicles to carry goods from farm (purchase place) to markets (serving places) and from rural market to the towns. In other cases, transport accounts for a large proportion of production costs. In some instances there are no roads where they exist they might be seasonal. Feeder roads are usually few and in most cases have to be construction and maintained by communal efforts.

Adegeye and Dittoh [8] reported that all effort has geared towards producing more without thinking about how to market them. There is need to know about new technologies in food storage preservation and marketing. Thus, there is need for research on consumers demand and preferences, handling and packaging to reduce lose in fruit and vegetable as well as in other agricultural produce marketing.

Some of these problems reported by Singh [6] include:

- $\quad$ Problems of price variability.

- Inadequate processing and storage facilities.

- $\quad$ Lack of information about production and marketing.

- $\quad$ Lack of transport facilities.

- $\quad$ Lack of uniform weight and measures.

- Inadequate research on fruit market, etc.

\section{Methodology}

\section{Area of the study}

Gombe state was created on $1^{\text {st }}$ October, 1996 by the military Government headed by General Sani Abacha, the commander-in-chief of Armed forces of the federation. It was formally under Bauchi state. The state has eleven local government councils with its administrative headquarters in Gombe.

Gombe state shares common boundary with Borno state in the east, Bauchi state by the west, Yobe state by the north and Adamawa state by the south. It is located in latitude $10^{\circ} 15^{\prime}$ north and longitude $11^{\circ}$ east. Her population is estimated of 1.5 million covering the area land mass of about 20, 265 square kilometer [10].

The area of the study was Balanga Local Government and it has covered three distinct areas in the local government namely, Maidara, Daban Magarya and Bakasi. The study area is located in co-ordinates $9^{0} 58^{\prime} \mathrm{N} 11^{\circ} 41^{\prime} \mathrm{E}$. Balanga is a local government area in the south east of Gombe State, Nigeria bordering Adamawa State. It's headquarters Talasse. It has an area of $1,626 \mathrm{Km}^{2}$ and a population of 212,549 at the 2006 census. The climate condition of the local government area is characterized by two distinct seasons, dry and wet. The hottest months are March and April which recorded up to a temperature of about $40-42^{\circ} \mathrm{C}$ while the coldest months are December to February with a minimum temperature of about $20-22^{\circ} \mathrm{C}$ and the area received the mean annual rainfall of $321.4 \mathrm{~mm} /$ annum [11].

\section{Sample procedure and sample size}

The data for this study were generated through the use of structured questionnaire complemented with oral interviews. The data were collected from sixty sweet melon producers in Balanga local government area of Gombe state. Purposive sampling technique was used to select three villages and proportional sampling was used in selecting twenty respondents from each village. Twenty questionnaires each were administered to sweet melon producers in Maidara, Daban Magarya and Bakasi. The data were collected by the researcher with help of two well trained personnel's within the period of eight weeks, beginning from June-July 2015.

\section{Method of data analysis}

The statistical tools employed in this study include descriptive statistics analysis, such as frequency distribution, percentage and mean were used for the analysis of socio-economic characteristics of sweet melon producers. The relationship between the socio-economic characteristics and production of sweet melon was determined using multiple regressions model. The model was specified as:

$\mathrm{Y}=\mathrm{f}\left(\mathrm{X}_{1}, \mathrm{X}_{2}, \mathrm{X}_{3}, \mathrm{X}_{4}, \mathrm{X}_{5}, \mathrm{X}_{6}, \mathrm{X}_{7}, \mathrm{X}_{8}, \mathrm{u}\right)$

Where,

$\mathrm{Y}=$ Output in Pyramid/Bill (Kg)

$\mathrm{X}_{1}=$ Age $($ Years $)$

$\mathrm{X}_{2}=$ Years of Experience (Years)

$\mathrm{X}_{3}=$ Farm Size $(\mathrm{Ha})$

$\mathrm{X}_{4}=$ Household Size (No. of Person)

$\mathrm{X}_{5}=$ Level of Education (Years)

$\mathrm{X}_{6}=$ Marital Status $(1=$ Married, others $=0)$ 
Citation: Omorogbe I, Aina OS, Yakubu SA, Hassan AA (2017) Socio-Economic Determinants of Sweet Melon Production in Balanga Local Government Area of Gombe State, Nigeria. J Biodivers Endanger Species 5: 180. doi: 10.4172/2332-2543.1000180

Page 3 of 5

\section{$\mathrm{X}_{7}=$ Extension Contact $(\mathrm{Yes}=1, \mathrm{No}=0)$ \\ $\mathrm{X}_{8}=$ Membership of Cooperative $(\mathrm{Yes}=1, \mathrm{No}=0)$ \\ $\mathrm{U}=$ Constant term}

The above model was specified and estimated in four functional forms. The functional forms tried include the linear, exponential, semi$\log$ and double-log. The functional form which gives the best fit in term of $\mathrm{R}^{2}$ value was selected because it agree with a priori expectation.

\section{Results and Discussion}

\section{Socio-economic characteristics of sweet melon producers}

Table 1 shows that majority (98.3) of the sweet melon producers in the study area were male. This implies that the participation of female in sweet melon production in the study area is very low. This agrees with the finding of Adamu et al., [5] who reported that males dominated the farming aspect of water melon in Kirfi Local Government Area of Bauchi State Nigeria. This is because most of the people in the study area are Muslims and "Purdah" is practice for female and house wives (not allowed in to farming) as enshrined in the culture of northern Nigeria. On marital status of the respondents, the results revealed that $95 \%$ of the sweet melon producers in the study area were married while only $5 \%$ were single in the study area. This is in line with study made by Atman et al., [12] which revealed that (98.99\%) of vegetable marketers in Yamaltu Deba Local Government of Gombe State, Nigeria were married. This is because majority of the producers in the area were Muslims and their religion permits them to marry at early ages. It is clear from the table that majority of the respondents were in the age category of 31-45 years representing $61.7 \%$ followed by those within the range of $16-30$ years with $20 \%$, those within the range of $46-60$ years represents $18.3 \%$, none of the respondent fall within the age of 61-75 years. The result further shows that a minimum of 19 and maximum of 53 years was recorded with a mean ages of the producers as 39 years, standard error of the mean was found to be $0.88 \%$ and $54.3 \%$ co-efficient of variability, implying that there is variability in the age of the respondents. The result depict that production of sweet melon in the study area are mostly carried out by relatively middle aged people. This category of people is believed to be more flexible in their decision making and adopt new ideas more readily, and the aged are risk-aversive. The results also indicated that $50 \%$ of the respondents attended Qur'anic schools, $23.3 \%$ had primary education, $16.7 \%$ had secondary education, while $8.3 \%$ had no formal education and $1.7 \%$ had attained tertiary education. The literacy level among the respondents was relatively high. It is expected that the sweet melon producers in the study area could readily adopt new ideas of agricultural production and can make accurate use of production decision. This is in line with the study made by Atman et al., [12] which reported that literacy status of respondents is necessary to explain the strength or weakness observed in their management ability and adoption of innovation. Educations are an important tool in increasing adoption of improved farm practices and ultimately improve in farm production and productivity. On occupation of the respondents, the result indicated that $43.3 \%$ of the sweet melon producers in the study area were engaged in farming alone; $33.3 \%$ engaged in farming and trading/business. $8.3 \%$ were into farming and livestock rearing while, $8.3 \%$ were sweet melon producers and civil service, $6.7 \%$ of the respondents were engaged in farming and others artisan activities such as driving, mechanic and car washing. The result means that majority of the respondents were full time farmers in the study area. The results revealed that majority had between $11-15$ and 16-20 persons in their

\begin{tabular}{|c|c|c|}
\hline & Frequency & Percentage \\
\hline \multicolumn{3}{|c|}{ Sex } \\
\hline Male & 59 & 98.3 \\
\hline Female & 1 & 1.7 \\
\hline \multicolumn{3}{|c|}{ Marital Status } \\
\hline Married & 57 & 95 \\
\hline Single & 3 & 5 \\
\hline \multicolumn{3}{|c|}{ Age } \\
\hline $16-30$ & 12 & 20 \\
\hline $31-45$ & 37 & 61.7 \\
\hline $46-60$ & 11 & 18.3 \\
\hline \multicolumn{3}{|c|}{ Educational Level } \\
\hline No formal Education & 5 & 8.3 \\
\hline Quaranic Education & 30 & 50 \\
\hline Primary Education & 14 & 23.3 \\
\hline Secondary Education & 10 & 16.7 \\
\hline Tertiary Education & 1 & 1.7 \\
\hline \multicolumn{3}{|c|}{ Occupation } \\
\hline Farming alone & 26 & 43.3 \\
\hline Farming and Trading & 20 & 33.3 \\
\hline Farming and Livestock & 5 & 8.3 \\
\hline $\begin{array}{l}\text { Farming and Civil } \\
\text { Services }\end{array}$ & 45 & 8.3 \\
\hline Farming and Artisanship & 4 & 6.7 \\
\hline \multicolumn{3}{|c|}{ Household Size } \\
\hline $1-5$ & 12 & 20 \\
\hline $6-10$ & 12 & 20 \\
\hline $11-15$ & 13 & 21.7 \\
\hline $16-20$ & 13 & 21.7 \\
\hline $21-26$ & 9 & 15 \\
\hline $27-30$ & 1 & 1.6 \\
\hline \multicolumn{3}{|c|}{ Years of Experience } \\
\hline $1-5$ & 56 & 93.3 \\
\hline $6-10$ & 4 & 6.7 \\
\hline \multicolumn{3}{|c|}{ Farm Size } \\
\hline $0.5-1$ & 29 & 48.3 \\
\hline $1.5-3$ & 31 & 51.7 \\
\hline \multicolumn{3}{|c|}{ Source of Finance } \\
\hline Family and Friend & 53 & 88.3 \\
\hline Bank Loan & 4 & 6.7 \\
\hline Cooperative Societies & 3 & 5 \\
\hline \multicolumn{3}{|c|}{ Cropping Pattern } \\
\hline Intercropping & 26 & 48.3 \\
\hline Sole Cropping & 20 & 33.3 \\
\hline Both & 14 & 23.4 \\
\hline
\end{tabular}

Table 1: Socioeconomic characteristics of respondents (Source: Field Survey, 2015).

households, representing 21.7\% each, Household size of 1-5 and 6-10 persons also had $20 \%$. The mean households' size of the respondents was found to be 13 persons with standard error of the mean of 0.25 , and co-efficient of variability of $23.7 \%$. The result clearly indicated that, the minimum number of persons in a household was found to be one with a maximum of 27 persons in the study area. The low variability among the household size is most likely attributed to polygamous nature in Northern Nigeria, similar to what was reported by Umoh [13] in Bauchi metropolis. The result also revealed that minimum year of experience was found to be 1 year with the maximum of 6 years. The mean years of experience of respondents was found to be 3.1 years, standard error of the mean value of 0.12 and the co-efficient of the variability of $28.7 \%$. This means that majority of the producers in the study area had not 
stayed long in the business because the fruit production was newly introduced to the area. The result indicated that majority (51.7\%) of the respondents had a farm size category of 1.5-3.0 hectares following by those in the category of $0.5-1.0$ hectare representing $48.3 \%$. The result further shows that a minimum of 0.5 and maximum of 3 hectares was recorded with mean hectares of 1.5 , standard error (SEX) of 0.008 and co-efficient of variability (CV) was found to be $1.19 \%$. This implies that the farmers have small-scale managed farms.

Majority $(88.3 \%)$ of the respondents sourced their initial capital through family and friends, $6.7 \%$ obtained their capital from bank loan while, only $5 \%$ obtained financial support from co-operative societies. This indicated, the only means of financing their business was through family and friends. This agrees with the findings of Atman et al. [12] who reported that, tomato producers and marketers were only financing their business through informal means that is through own savings, money lenders, family and friends), as none of the respondent's claimed to have obtained money for financing his business from government. The result indicated that majority $(43.33 \%)$ of the sweet melon producers engaged in intercropping pattern while $33.33 \%$ of the respondents were engaged in sole cropping and only $23.33 \%$ were engaged in both sole and inter cropping. This is in line with the study by Yusuf et al., [14] which stated that the higher the number of crops in the mixture the less the profitability. Also Yusuf [15], discovered in his research on Egusi melon that the more the number of crops in the mixture the less the yield and the less the profitability, which he attributed to the competitive effects of the various crop in the mixture (Table 1).

\section{Regression results for the socio-economic determinants of sweet melon production}

Multiple regression analysis was used to determine the socioeconomic factors influencing the sweet melon production in the study area. In order to compare and assess in detail the necessary parameters, four functional forms viz: linear, double-log, semi log, and exponential function were fitted to the data. The result presented in Table 2 shows the estimated impacts of socio-economic factor of respondent on production output (age, experience, farm size, house hold size, education attainment, married status). Double-log function was found to have the best fit and therefore chosen as the best lead equation. The $\mathrm{R}^{2}$ of the double-log function was found to be 0.768 . This implies that about $76.8 \%$ of the variation in output of the respondent was accounted for by joint action of the six independents factor while the rest $23.2 \%$ of the variation was due to error. The overall regression result was significant with F-statistic value of 35.717 at 5\% level of probability. The regression co-efficient of experiences, farm size and house hold size were significant at $5 \%$ level of probability, therefore, making the three factors important determinant of output from sweet melon production. The other three factors age, education attainment and marital status were not significant and therefore, constituted weak determinants of production output. Farmers with high experience are more likely to produce more sweet melon than their counterparts with low experience, and also farmers with large farm size are more likely to produce more melon with their counterparts with small farm sizes and the farmers with large house hold size are more likely to produce more sweet melon than their counterparts with small household size which are similar to Ugwumba [16].

\section{Conclusion}

The study was conducted in Balanga Local Government Area, Gombe State. The main objective of the study is to obtained information

\begin{tabular}{|c|c|c|c|c|}
\hline Factors & $\begin{array}{c}\text { Linear } \\
\text { Function }\end{array}$ & $\begin{array}{c}\text { Semi-Log } \\
\text { Function }\end{array}$ & $\begin{array}{c}\text { Double-Log } \\
\text { Function }\end{array}$ & $\begin{array}{c}\text { Exponential } \\
\text { Function }\end{array}$ \\
\hline Constant & $\begin{array}{c}338.245 \\
(0.269)\end{array}$ & $\begin{array}{c}670.601 \\
(1.223)\end{array}$ & $\begin{array}{c}3.617 \\
(10.479)^{\star *}\end{array}$ & $\begin{array}{c}3.071 \\
(35.889)^{\star *}\end{array}$ \\
\hline Age & -0.110 & -0.186 & -0.168 & -0.86 \\
$(-0.780)$ & $(-1.073)$ & $(-1.409)$ & $(-0.825)$ \\
\hline Experience & 0.519 & 0.463 & 0.583 & 0.598 \\
\hline Farm Size & $(4.780)^{\star *}$ & $(3.846)^{\star *}$ & $(7.065)^{\star *}$ & $(7.419)^{\star *}$ \\
\hline House Hold & 0.312 & 0.362 & 0.317 & 0.245 \\
\hline Size & $(2.752)^{\star *}$ & $(2.839)^{\star *}$ & $(3.625)^{\star *}$ & $(2.909)^{\star *}$ \\
\hline Education & 0.158 & 0.155 & 0.268 & 0.256 \\
Attainment & $(1.249)$ & $(0.869)$ & $(2.191)^{\star *}$ & $(2.734)^{\star *}$ \\
\hline Marital Status & $(0.097)$ & 0.030 & 0.025 & 0.013 \\
\hline F-Statistic & -0.005 & - & $(0.382)$ & $(0.185)$ \\
\hline $\mathbf{R}^{2}$ & $11.070^{\star *}$ & $11.109^{\star *}$ & - & 0.68 \\
\hline $\mathbf{R}^{2}$ Adjusted & 0.556 & 0.507 & 0.768 & $(0.831)$ \\
\hline
\end{tabular}

Note: Figure in parenthesis is the t-test values, ${ }^{* *}$ : Statistically significant at $5 \%$. (Source: Computed from Survey Data, 2015).

Table 2: Regression results for the socio-economic determinants of sweet melon production

on socio-economic determinant of the respondents, in achieving these objectives; three villages (Maidara, Daban Magarya and Bakasi Areas) were purposively selected. Sixty respondents were randomly selected from the list frame of the sweet melon farmers. The respondents were issued with questionnaires, which were filled with the help of well trained enumerators and the researcher. Statistical tools such as descriptive statistics and multiple regression analysis were used in data analysis. The major findings of this study revealed that the majority of the sweet melon producers were male, married and were within the age bracket of 31-45 years with mean age of 39 years. The result further showed that the respondent had one form of education or the other with Qur'anic education as the highest up to $50 \%$, and had 1-5 years experience with the mean 3.1 years of experience. Moreover, the result also showed that $43.3 \%$ of the respondents engage in farming alone and mainly sources their initial capital for the business through family and friends been $(88.3 \%)$. The regression analysis of the socio-economic characteristics show that double-log regression was chosen as the lead equation based on the values of $\mathrm{R}^{2}$ of 0.768 with a standardized co-efficient of 0.256 . The regression co-efficient of experiences, farm size and the house hold size were significant at $5 \%$ level of probability, therefore, making the three factors important determinant of output from sweet melon production.

\section{Recommendation}

Based on the findings the following recommendations were made:

1. Socio-economic characteristic of sweet melon farmers should be taken into consideration when formulating policies and also when introducing new technologies to rural farmers.

2. Provision of credit facilities with less bureaucracy and low interest rate to producers. This will enable farmers to increase their farm size and in turn increase their output.

3. Extension agent should be mobilized in the area to enhance the level of agronomic practices of melon farmers. Access to extension agents enhances the chances of having access to better crop production techniques, improved inputs as well as other production incentives and in turn leads to increase in output. 
Citation: Omorogbe I, Aina OS, Yakubu SA, Hassan AA (2017) Socio-Economic Determinants of Sweet Melon Production in Balanga Local Government Area of Gombe State, Nigeria. J Biodivers Endanger Species 5: 180. doi: 10.4172/2332-2543.1000180

Page 5 of 5

\section{References}

1. Food and Agriculture Organization (2000) Food and Agricultural Organization of the United Nations in: AO (1990). Assessing Agricultural Commodity Price Variability, Economic Research Services/USDA Risk Management, p: 16.

2. Makhura MT (2002) Overcoming the Transaction Cost Barriers to Market participation of Smanholder Farmers in the Northern Province. University of Protein, Pretoria.

3. Wyllie SH, Leach DN, Wang YM, Shewfelt PL (1995) Key Aroma Compounds in Melons: Their Development and Cultivar Dependence. In: Rousseff RL and Leahy MM (eds.) Fruit Flavours: Biogenesis, Characterization and Etherification. Am Chem S, Washington DC, USA, pp: 248-257.

4. Olukosi JO, Isitor SU (1990) Introduction to Agricultural Production Economics: Principels and Applications. Agitob Publishers Ltd., Zaria, p: 112.

5. Adamu Y, Hamidu K, Mahmoud BA (2011) Profitability of water melon marketing in Kirfi Local Government Area of Bauchi State, Nigeria. Paper presented in the preceding of the $25^{\text {th }}$ Annual national Conference of Farm Management Association of Nigeria.

6. Singh BR (2004) Constraints to Sustainable Crop Production in Semi and North West of Nigeria. The Nigerian J Agr Rural Manag 7: 40-62.

7. Dieter E (1985) Agricultural Marketing Policies and Development: Agricultural marketing Strategy and Pricing Policy, pp: 5-12.
8. Adegeye AJ, Dittoh (1985) Essentials of Agricultural Economics. Published by Impact Publichsers, Nigeria Limited Ibadan, pp: 164-181.

9. Abbot JC (1985) Marketing Problems and Improvement Programmes FAO Rome, pp: 1-14.

10. National Population Commission (2006) National Population Report, Abuja, Nigeria.

11. Gombe State Metrological Station (2012) Bulletin, pp: 11-13.

12. Atman FM, Haruna U, Sani RM (2008) Profitability of tomato production and marketing in Yamaltu Deba LGA of Gombe State, Nigeria. $9^{\text {th }}$ Annual Nation Conferences of Nigeria Association of Agricultural Economic Proceeding.

13. Umoh GS (2006) Resource use Efficiency in Urban Farming. An Application of Stochastic Frontier Production Function. Int J Agr Biol 8.

14. Yusuf O, Sanni SA, Ojuekaiye EO, Ugbabe OO (2008) Profitability of “Egusi” Melon (Citrullus Lanaltus Mansf) Production Under Sole and Mixed Cropping Ssytems in Kogi State Nigeria. Asian Research Publishing Network (ARPN), J Agr Biol S 3: 14-18.

15. Yusuf O (2005) Economic Analysis of "Egusi" Melon Production in Okehi Local Government Area of Kogi State. Department of Agricultural Economics and Rural Sociology Ahmadu Bello University, Zaria.

16. Ugwumba COA (2010) Resource use Efficiency and Determinants of Cat Fish Production Output in Anambra State, Nigeria. 